\title{
Dietary protein - its role in satiety, energetics, weight loss and health
}

\author{
Margriet S. Westerterp-Plantenga*, Sofie G. Lemmens and Klaas R. Westerterp \\ Human Biology, Nutrim, MUMC, Maastricht University, PO Box 616, 6200 MD, The Netherlands
}

(Submitted 27 July 2011 - Final revision received 29 September 2011 - Accepted 18 November 2011)

\begin{abstract}
Obesity is a serious health problem because of its co-morbidities. The solution, implying weight loss and long-term weight maintenance, is conditional on: (i) sustained satiety despite negative energy balance, (ii) sustained basal energy expenditure despite BW loss due to (iii) a sparing of fat-free mass (FFM), being the main determinant of basal energy expenditure. Dietary protein has been shown to assist with meeting these conditions, since amino acids act on the relevant metabolic targets. This review deals with the effects of different protein diets during BW loss and BW maintenance thereafter. Potential risks of a high protein diet are dealt with. The required daily intake is $0.8-1 \cdot 2 \mathrm{~g} / \mathrm{kg} \mathrm{BW}$, implying sustaining the original absolute protein intake and carbohydrate and fat restriction during an energy-restricted diet. The intake of $1.2 \mathrm{~g} / \mathrm{kg} \mathrm{BW}$ is beneficial to body composition and improves blood pressure. A too low absolute protein content of the diet contributes to the risk of BW regain. The success of the so-called 'low carb' diet that is usually high in protein can be attributed to the relatively high-protein content per se and not to the relatively lower carbohydrate content. Metabolic syndrome parameters restore, mainly due to BW loss. With the indicated dosage, no kidney problems have been shown in healthy individuals. In conclusion, dietary protein contributes to the treatment of obesity and the metabolic syndrome, by acting on the relevant metabolic targets of satiety and energy expenditure in negative energy balance, thereby preventing a weight cycling effect.
\end{abstract}

Key words: protein-diet: satiety: energy expenditure: sparing fat-free-mass: obesity: metabolic syndrome

\section{Introduction}

Obesity is a serious health problem because of its comorbidities ${ }^{(1,2)}$. The solution for this problem implies weight loss and long-term weight maintenance, which is difficult to achieve, since body-weight (BW) regain appears to be the pitfall ${ }^{(1,3)}$. The approach for this solution is conditional on: (i) sustained satiety despite negative energy balance, (ii) sustained basal energy expenditure despite BW loss due to (iii) a sparing of fat-free mass (FFM) (being the main determinant of basal energy expenditure $)^{(4)}$. Dietary protein has been shown to assist with meeting these conditions, since amino acids act on the metabolic targets involved in satiety, energy expenditure, and the sparing of $\mathrm{FFM}^{(3,4)}$. This review, on dietary protein and its role in satiety, energetics, BW loss and health, deals with the effects of different protein diets during $\mathrm{BW}$ loss and $\mathrm{BW}$ maintenance thereafter, and on the crucial metabolic targets, namely satiety and energy expenditure. Potential risks of a high protein diet are dealt with.

Normal and high-protein diets need to be defined in both relative and absolute terms in relation to energy balance. Relatively high-protein diets for $\mathrm{BW}$ loss and subsequent BW maintenance have at least $25-30 \%$ of their energy supplied from protein, implying a sustained normal-protein intake in grams of $0 \cdot 8-1 \cdot 2 \mathrm{~g} / \mathrm{kg} \mathrm{BW}$, as it was before the diet. However, total energy intake is decreased. Such diets are relatively high in protein, expressed as a percentage energy (En\%) from protein (20-30 En\%), but since they are energy-restricted, in absolute terms ( $g$ of protein) they only contain a sufficient absolute amount of protein. The absolute amount of protein is about the same as in a relatively normalprotein diet (10-15 En\% protein) in neutral energy balance (energy intake matches energy requirement set by energy expenditure).

\section{Dietary protein and body weight management}

Studies suggest that BW loss and BW maintenance thereafter, on a relatively high-protein diet, appear to be greater under conditions of ad libitum energy intake than under conditions of isoenergetic diets ${ }^{(4)}$. The explanation for this is that satiety is a key factor in applying relatively high-protein diets. Under ad libitum feeding conditions subjects eat less from the relatively high-protein diet than under iso-energetically fed conditions ${ }^{(5)}$. Such diets contain a sufficient absolute amount of protein but lead to decreased energy intake, suggesting that in addition to metabolic effects of protein on BW loss, energy intake plays an important role. This is underscored by the phenomenon that under iso-energetic conditions no

*Corresponding author: Prof. Dr M. S. Westerterp-Plantenga, fax +31433670976, email m.westerterp@maastrichtuniversity.nl 
statistically significant difference between BW loss on a highprotein or high-carbohydrate diet is shown. ${ }^{(3-5)}$ However, most of the studies on protein intake in relation to $\mathrm{BW}$ management show an improved body composition (i.e. an increased $\mathrm{FFM} /$ fat mass (FM)) and metabolic profile with a relatively high-protein diet. The relatively high-protein negative energy balance diets, in general supply $20-30 \%$ of their energy from protein and imply a required normal-protein intake in grams, while energy intake is decreased ${ }^{(4)}$.

The observations with respect to energy efficiency during $\mathrm{BW}$ regain are comparable to the 'Stock hypothesis' described for $\mathrm{BW}$ gain $^{(6)}$. Under conditions of slight $\mathrm{BW}$ regain, while aiming for weight maintenance, a required-protein diet shows reduced energy efficiency related to the body composition of the BW regained, (i.e. in favour of FFM). Here, the main issue is that building FFM requires, on average, an additional energy ingestion of $52 \mathrm{MJ} / \mathrm{kg} \mathrm{BW}$, whereas building a normal proportion of FM and FFM takes $30 \mathrm{MJ} / \mathrm{kg} \mathrm{BW}^{(6)}$. During BW loss, as well as during weight maintenance thereafter, a relatively high (but absolutely normal) protein diet preserves or increases FFM and reduces FM, and improves the metabolic profile. Evidence shows that the requiredprotein intake sustains weight maintenance by: (i) favouring regain of FFM at the cost of FM at a similar physical activity level, (ii) reducing the energy efficiency with respect to the BW regained, and (iii) increasing satiety ${ }^{(4)}$.

\section{Dosage of protein during an energy-restricted diet}

Studies describing assessment of effects of relatively high vs. normal-protein diets on BW management ${ }^{(3-5,7-15)}$ often are assessing absolutely normal vs. low-protein diets. To answer the question as to whether diets absolutely high in protein may show a higher BW loss, improved body composition, and stronger BW maintenance after BW loss compared with protein diets at the required level of protein intake, the following study was undertaken (S Soenen, unpublished data). In 72 obese subjects BW, body composition, and metabolic parameters were assessed before and after dietary energy intakes of $100 \%, 33 \%$, and $67 \%$ of the individuals original daily energy requirement, for respectively $0.5,1.5$ and 4 months. The diets consisting of a required-protein diet, which met the daily protein requirement, RPD, and a highprotein diet, HPD, as protein/carbohydrate/fat at baseline, gave consistent protein intakes of $0.8 \pm 0.3 \mathrm{~g} / \mathrm{kg} \mathrm{BW}$ (RPD) and $1.2 \pm 0.3 \mathrm{~g} / \mathrm{kg}$ BW (HPD) $(P<0.001)$ throughout the study. Both diets were equally effective in supporting BW loss, the loss of body-fat, BW maintenance, and both diets showed a FFM sparing effect, which was however stronger in the high-protein diet, similar to previous observations $^{(3-5,7-15)}$. This higher FFM sparing effect prevented a decrease of resting energy expenditure as a function of FFM, thereby facilitating maintenance of reduced BW, as has been shown before ${ }^{(3-5,7-15)}$. Reduction of BW was equally facilitated by the satiety capacity of protein ${ }^{(3-5,7-15)}$, which contributes to compliance to the $\operatorname{diet}^{(3,4,8,10)}$, as well as "attitude-towardeating". The plasma concentrations of the peptides glucagonlike peptide-1 (GLP-1) and peptide-YY (PYY) similarly decreased over time, probably due to less nutrients being present in the gut. Physical activities, as recorded using the Baecke questionnaire, were not affected by the diets. The observation that both diets were similarly effective for (BW) loss, FM loss, and BW maintenance thereafter confirms earlier observations, ${ }^{(16-20)}$ which reported no difference between two levels of protein in the diet. In those diets, the 'normal' or 'low' protein content, still provides sufficient protein $(\sim 60 \mathrm{~g})$, to sustain satiety, FFM, and energy expenditure, and the diet thus shows a similar effect on BW loss as a diet higher in protein content. However, when the control diet provided an insufficient amount of protein, a rapid BW regain was shown, similar to the effect seen on most diets that, due to a limited energy content, do not provide a sufficient amount of protein $^{(5,7,9,12-15,17)}$. Thus, a controlled, energy-restricted "normal-protein" diet providing at least $0.8 \mathrm{~g}$ Protein $/ \mathrm{kg}$ BW is sufficient for substantial weight loss, subsequent weight maintenance, and a decrease in body fat percentage (BF\%), while a controlled high-protein diet providing $1.2 \mathrm{~g}$ protein $/ \mathrm{kg}$ $\mathrm{BW}$ is necessary for improvement of FFM and a sustained resting energy expenditure. The effect of a higher protein diet on body composition has not only been shown before during BW loss and BW maintenance thereafter ${ }^{(3-5,7-15,16-20)}$, but also in a longer-term study in energy balance ${ }^{(21,22)}$. We suggest that a too low absolute protein intake contributes to the risk of BW regain. An "absolutely required" amount of protein in the diet $(0 \cdot 8 \mathrm{~g} / \mathrm{kg} \mathrm{BW} / \mathrm{d})$ is sufficient for weight loss, body fat loss, and weight maintenance; yet, an "absolutely elevated" amount of protein in the diet, thus the real high-protein diet of $1.2 \mathrm{~g} / \mathrm{kg} \mathrm{BW} / \mathrm{d}$, is necessary for improving FFM and resting energy expenditure (16). In further studies it was assessed whether including specific proteins, such as gelatin or alphalactalbumin, may improve the effect described above, due to their high satiating capacities (see below). However, this was not the case ${ }^{(23-25)}$.

\section{Effects of 'low-carb diets' in combination with 'high-protein' diets}

'Low carb' diets compared with control diets have been suggested to be relatively more effective in BW management. However, these diets are relatively high in protein as well. Here the question was whether a decrease in carbohydrate or an increase in daily absolute protein intake has a stimulating effect on reducing $\mathrm{BW}$ and $\mathrm{BF} \%$.

A study with four different energy restriction diets offered parallel in a $2 \times 2$ factorial design, (contrasting in low vs. normal-carbohydrate intake and high vs. normal-protein intake, addressed whether it was the high-protein or lowcarbohydrate factor that was crucial for the effect. The study showed irrefutably that, despite all four diets supporting weight loss, the answer is that it is the relatively high-protein content per se that underscores the even greater success, and not the relatively lower carbohydrate content and even that a high-protein normal-carbohydrate regimen shows relatively less regain, so better weight-maintenance.

A suggested mechanism underscoring the decrease of BW of an elevated protein, lowered carbohydrate, and relatively 
high-fat diet is the satiety effect created by the ketogenic state of the diet. The formation of ketone bodies such as $\beta$-hydroxybutyrate ${ }^{(26-28)}$ is related to appetite reduction and a greater reduction of $\mathrm{BW}$ in humans ${ }^{(26-28)}$. Moreover, this type of diet increases energy expenditure, supporting a negative energy balance, via increased gluconeogenesis ${ }^{(29,30)}$. However, in the long-term, compliance to this type of diet is not consistent.

\section{Dietary protein and health}

One of the greatest health problems, overweightness and obesity including many co-morbidities, can be treated successfully by a high protein diet, which implies that simply BW loss and BW maintenance can reverse metabolic problems. Indeed, it has been shown convincingly that the metabolic profile including insulin sensitivity and lipid metabolism remarkably improve, mainly as an effect of BW loss, indicating that the originally inferior metabolic profile was probably the effect and not the cause of overweight. Blood pressure also decreases in relation to a decrease in FM. With respect to possible adverse events, some caution is needed when dietary protein intake is elevated in an absolute sense for a longer period of time. There may be adverse effects on the kidneys, related to elevated blood pressure. Especially individuals with sub-clinical renal malfunction, such as due to metabolic syndrome or type 2 Diabetes Mellitus, and elderly are vulnerable. However, the link between protein intake and the initiation or progression of renal disease lacks evidence in healthy individuals $^{(4)}$. In those healthy individuals, high-protein diets did not affect kidney function parameters. Plasma creatinine concentrations remained between the normal values of $60-120 \mu \mathrm{mol} / \mathrm{L}$. Moreover, the diets resulted in a decrease in systolic and diastolic blood pressure after BW loss.

\section{Dietary protein and energetics}

One of the metabolic targets required of high-protein diets is to sustain energy expenditure, even in negative energy balance, to prevent the BW cycling effect. The thermogenic effect of protein is clearly illustrated by the difference between the gross energy value of $22-25 \mathrm{~kJ} / \mathrm{g}$ and the net metabolizable energy value of $13 \mathrm{~kJ} / \mathrm{g}$. The effect of protein intake on energy expenditure is reflected mainly in two of the four components that daily energy expenditure consists of (i.e. the sleeping metabolic rate (SMR) and the energy cost of arousal forming together the energy expenditure for maintenance or basal metabolic rate (BMR), and the thermic effect of food or diet induced energy expenditure (DEE) $)^{(4)}$. Reported DEE values for separate nutrients are 0 to $3 \%$ for fat, 5 to $10 \%$ for carbohydrate, 20 to $30 \%$ for protein (4), and 10 to $30 \%$ for alcohol ${ }^{(4)}$. In healthy subjects with a mixed diet, DEE represents about $10 \%$ of the total amount of energy ingested over $24 \mathrm{~h}$. When a subject is in energy balance, where intake equals expenditure, DEE is $10 \%$ of daily energy expenditure $^{(4)}$. In a few studies conducted over $24 \mathrm{~h}$ in a respiration chamber ${ }^{(31,32)}$ healthy female volunteers were fed high-protein high/carbohydrate (En\% protein/carbohydrate/ fat 30/60/10) and high-fat diets (En\% protein/carbohydrate/ fat 10/30/60). Both diets were isoenergetic and isovolumetric, and composed of normal food items, which matched organoleptic properties (taste, smell, and appearance). Subjects each spent two $36 \mathrm{~h}$ periods in a respiration chamber consuming both test diets in random order. DEE was higher in all subjects when on the high-protein high-carbohydrate diet. Even when the protein type was casein alone a similar difference in energy expenditure was shown ${ }^{(33,34)}$. Effects of two diets with either $25 \mathrm{En} \%$ or $10 \mathrm{En} \%$ from casein or gelatin as the only protein sources, on energy expenditure, substrate balance, and appetite profile were studied during $36 \mathrm{~h}$ stays in a respiration chamber, in 24 healthy normal weight subjects (12 men and 12 women). It appeared that the high casein and gelatin diets $(25 \mathrm{En} \%)$ resulted in a higher $24 \mathrm{~h}$ total energy expenditure (2.6\%) and a higher SMR (2.1\%) compared with comparable 10 En\% casein or gelatin diets. Moreover, with the $25 \mathrm{En} \%$ diets, compared with the $10 \mathrm{En} \%$ diets, the subjects were in positive protein balance and negative fat balance, while satiety was 33\% higher. The 25 En\% diets boosted energy expenditure, protein balance, satiety, and negative fat balance, which is beneficial to BW management ${ }^{(33,34)}$. Combining the studies on protein intake, DEE and SMR, it can be concluded that protein intake causes an acute increase in DEE and, when sustained over three days, results in an increase in SMR as well. The effects on energy expenditure and protein balance were stronger with the casein diet compared with the gelatin diet, due to the completeness of the protein. Due to the incompleteness of gelatin, the carbohydrate balance was also more positive, possibly due to gluconeogenesis.

\section{Gluconeogenesis}

A further respiratory chamber study on energy expenditure paid specific attention to gluconeogenesis and its effect on energy expenditure ${ }^{(29,30)}$. Ten healthy lean young men received an isoenergetic high-protein carbohydrate-free diet (En\% protein/carbohydrate/fat 30/0/70) or a normal-protein diet (En\% protein/carbohydrate/fat 12/55/33) for $1.5 \mathrm{~d}$ according to a randomized crossover design, and energy expenditure was measured in a respiration chamber. Endogenous glucose production (EGP) and fractional gluconeogenesis were measured via infusion of [6,6-(2) H(2)]glucose and ingestion of (2) $\mathrm{H}(2) \mathrm{O}$; absolute gluconeogenesis was calculated by multiplying fractional gluconeogenesis by EGP. Body glycogen stores were lowered at the start of the intervention with an exhaustive glycogen-lowering exercise test. EGP was lower in the carbohydrate-free condition than in the control condition, whereas fractional and absolute gluconeogenesis were higher. Resting metabolic rate was higher in the carbohydrate-free condition than in the normal-protein condition. Forty-two percent of the increase in energy expenditure after the high-protein carbohydrate-free diet was explained by the increase in gluconeogenesis ${ }^{(29,30)}$. The ATP required for the initial steps of metabolism and oxidation including urea synthesis might explain the short-term protein induced increase in DEE. The long-term protein induced increase of 
SMR might be explained by stimulation of body protein synthesis and protein turnover ${ }^{(35)}$. A well-balanced amino acid mixture produces a higher thermogenic response than does an amino acid mixture with a lower biological value (i.e. a different amino acid composition than is used for protein synthesis). This may explain why the intake of plant protein results in less protein synthesis than does the intake of animal protein

\section{Dietary protein and satiety}

Although it has been shown repeatedly that acute high-protein meals induce satiety ${ }^{(4)}$, we will focus here on relatively highprotein diets instead.

When high-protein menus are offered at each meal, lasting for one to several days, one gets into the condition of a high-protein diet once metabolic reactions have been established $^{(32-34,36,37)}$. In several high-protein diet studies in normal-weight healthy subjects, a continuously higher satiety has been shown throughout the day following a high compared with a normal-protein diet; for instance in the energy balance controlled environment of a respiration chamber ${ }^{(32-34,36,37)}$. Here, a normal-protein diet given in energy balance contains $10-15 \mathrm{En} \%$ protein $^{(32-34,36,37)}$, and a high-protein diet in energy balance contains 20-30 En\% protein $^{(32-34,36,37)}$. A high-protein diet in the presence of carbohydrate stimulates GLP-1 release ${ }^{(32-34,36,37)}$, which triggers insulin release. More importantly, only high-protein diet-induced satiety is primarily related to elevated energy expenditure $^{(32-34,36,37)}$, implying increased oxygen consumption and an increase in body temperature both leading to a feeling of being deprived of oxygen and thus promoting satiety $^{(32-34,36,37)}$. These highly-controlled medium term studies overcome possible differences due to solid, semisolid, or liquid foods, timing and macronutrient exchange ${ }^{(4)}$, and imply the possibility of assessing satiety, energy expenditure and substrate oxidation at the same time. More of these types of studies need to be executed with different types of proteins, in overweight subjects in neutral, positive and negative energy balances.

\section{Mechanisms behind protein-induced satiety}

There appears to be a band-width in protein amount and concentration where relatively more protein is more satiating and promotes less energy intake (Figs. 1-4), supported by relatively elevated plasma amino acid concentrations, anorexigenic hormones, or energy expenditure, feeding back on the central nervous system. Mellinkoff ${ }^{(38)}$ suggested already in 1956 that an elevated concentration of blood or plasma amino acids, which cannot be channeled into protein synthesis, serves as a satiety signal for a food intake regulating mechanism and thereby results in depressed food intake.

The quality or type of protein appears to be involved in hunger suppression. Protein quality is mainly determined by the amino acid composition of the protein. Some proteins are considered as 'incomplete' or 'lower quality' proteins because they are lacking one or more dietary essential

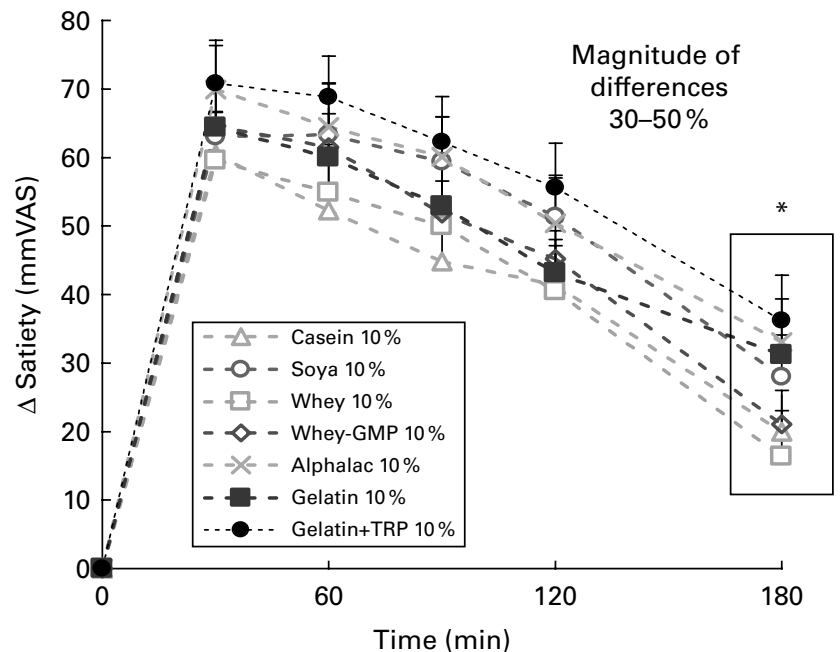

Fig. 1. Comparison of VAS-ratings of feelings of increased satiety (or fullness) between post-prandial effects of 7 different proteins, namely casein, soya, whey, whey-GMP, alpha-lactalbumin, gelatin, gelatin plus tryptophan, during $3 \mathrm{~h}$ after an iso-energetic, iso-volumetric semi-solid breakfast, with the same controlled appearance, taste, flavour, energy-density and viscosity, at $20 \%$ of the energy-requirement of the individual subject, and with a single protein dosage of $10 \%$ of energy. $\mathrm{N}=24$. After Veldhorst et al., $2009^{(39)}$.

amino acids or have an inadequate dietary essential amino acid balance ${ }^{(23,24,34,39)}$. Gelatin is considered as an incomplete protein because it is lacking tryptophan (TRP) and contains relatively low amounts of the other dietary essential amino acids (i.e. histidine, isoleucine, leucine, lysine, methionine, phenylalanine, threonine, and valine). The addition of TRP does not improve the protein quality of gelatin to a large extent. Both gelatin and gelatin with added TRP suppress hunger more than other types of protein: subsequent energy intake was decreased after a breakfast with gelatin or gelatin with added TRP compared with casein, soya, whey, or whey without glycomacropeptide (GMP) ${ }^{(39)}$. This is probably attributable to the low protein quality of gelatin and gelatin with added TRP. It has been shown that animals reject diets that lead to depletion or deficiency of dietary essential amino acids (the 'indispensable amino acid deficiency' theory). After rejection of such a diet animals begin foraging for a better dietary essential amino acid source and develop conditioned aversions to cues associated with the deficient $\operatorname{diet}^{(23,24)}$. A chemosensor for dietary essential amino acid deficiency has been found in the anterior piriform cortex $^{(23,24)}$. From this area signals are projected to other brain areas that are associated with the control of food intake ${ }^{(23,24)}$. Likewise, consumption of an incomplete protein may be detected and result in a signal to stop eating in humans ${ }^{(38)}$. The observed increased gelatin-induced satiety and reduced energy intake thus may be a signal of hunger suppression rather than a satiation or satiety signal ${ }^{(39)}$.

A different mechanism implies a ketogenic state contributing to appetite suppression: a high-protein, high-fat, carbohydrate-free diet induced an increased dietary fat oxidation and increased concentration of ketone bodies and suppressed 


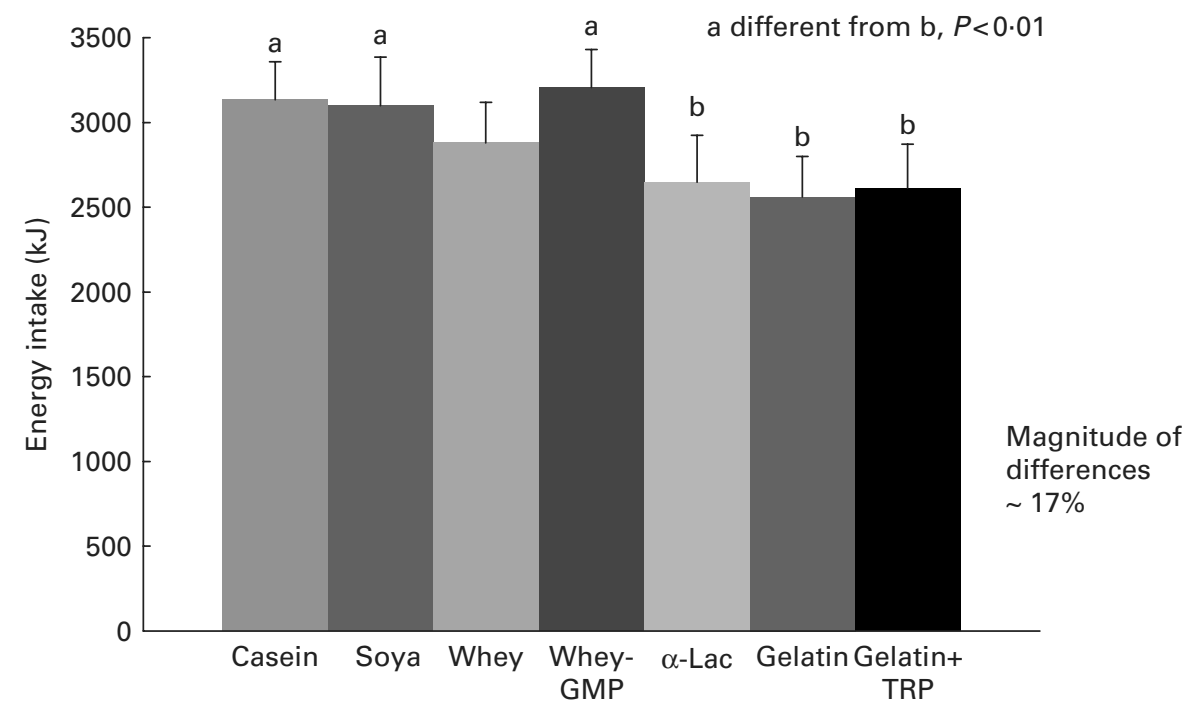

Fig. 2. Energy intake three hours after an iso-energetic, iso-volumetric semi-solid breakfast, with the same controlled appearance, taste, flavour, energy-density and viscosity, at $20 \%$ of the energy-requirement of the individual subject, and with a single protein dosage of $10 \%$ of energy. $\mathrm{N}=24$. Comparison between postprandial effects of 7 different proteins, namely casein, soya, whey, whey-GMP, alpha-lactalbumin, gelatin, gelatin plus tryptophan. After Veldhorst et al., 2009(39).

appetite more than a high-protein, normal-fat, normalcarbohydrate diet ${ }^{(26-28,30)}$. Increased dietary fat oxidation is suggested to reduce appetite whereas inhibition of fatty acid oxidation increases food intake ${ }^{(30)}$. The reduction of appetite with increased dietary fat oxidation may be due to stimulation of carnitine palmitoyl transferase-1 (CPT-1), a catalyst of the rate-limiting step in mitochondrial fatty acid oxidation. Increased fat oxidation with low-carbohydrate availability results in the production of ketone bodies ${ }^{(26-28,30)}$. Ketone bodies are formed from amino acids, hence consumption of a diet that is high in ketogenic amino acids results in an increased production of ketone bodies. $\beta$-Hydroxybutyrate, which is the most important ketone body in the blood $^{(26-28,30)}$, reduced food intake after intracerebroventricular infusion or subcutaneous injection in rats ${ }^{(26-28)}$. Leucine and lysine are the only two amino acids that are solely ketogenic amino acids; isoleucine, phenylalanine, TRP, and tyrosine are both ketogenic and glucogenic ${ }^{(26-28,30)}$. High-protein diets with proteins that predominantly consist of ketogenic amino acids may result in increased plasma ketone body concentrations, which in turn may contribute to increased satiety. Whey and alpha-lactalbumin have relatively high leucine and lysine contents which may have contributed to the increased satiety with whey compared with casein or soya, and the satiety with alpha-lactalbumin compared with casein, soya, and whey ${ }^{(40-42)}$.

Changes in concentrations of gastrointestinal (an) orexigenic hormones have been hypothesized to contribute to differences in these satiating efficacies of different types of proteins $^{(33,34,36)}$. Variations in concentrations of these hormones are directly recorded by the central nervous system and thereby may affect the control of food intake, but until now this lacks sufficient evidence ${ }^{(33,34,36)}$.

\section{Protein turnover and metabolism}

Protein turnover and metabolism are strongly influenced by protein quality because protein synthesis requires an adequate availability of dietary essential amino acids. In other words, the intake of sufficient amounts of these amino acids is crucial for preventing negative protein turnover. A specific appetite for essential amino acids has therefore been suggested, which is supported by the observation that rats, when fed a diet deficient in one or more dietary essential amino acids, are able to recognize the presence of these amino acids in a range of diets with or without these amino acids ${ }^{(43,44)}$. Such

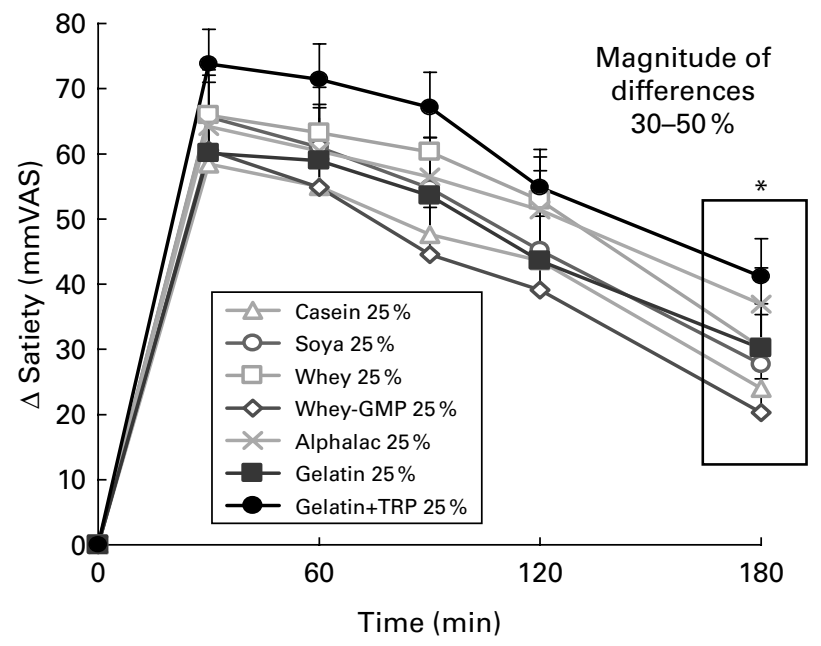

Fig. 3. Comparison of VAS-ratings of feelings of increased satiety (or fullness) between post-prandial effects of 7 different proteins, namely casein, soya, whey, whey-GMP, alpha-lactalbumin, gelatin, gelatin plus tryptophan, during $3 \mathrm{~h}$ after an iso-energetic, iso-volumetric semi-solid breakfast, with the same controlled appearance, taste, flavour, energy-density and viscosity, at $20 \%$ of the energy-requirement of the individual subject, and with a single protein dosage of $25 \%$ of energy. $\mathrm{N}=24$. After Veldhorst et al., $2009^{(39)}$. 


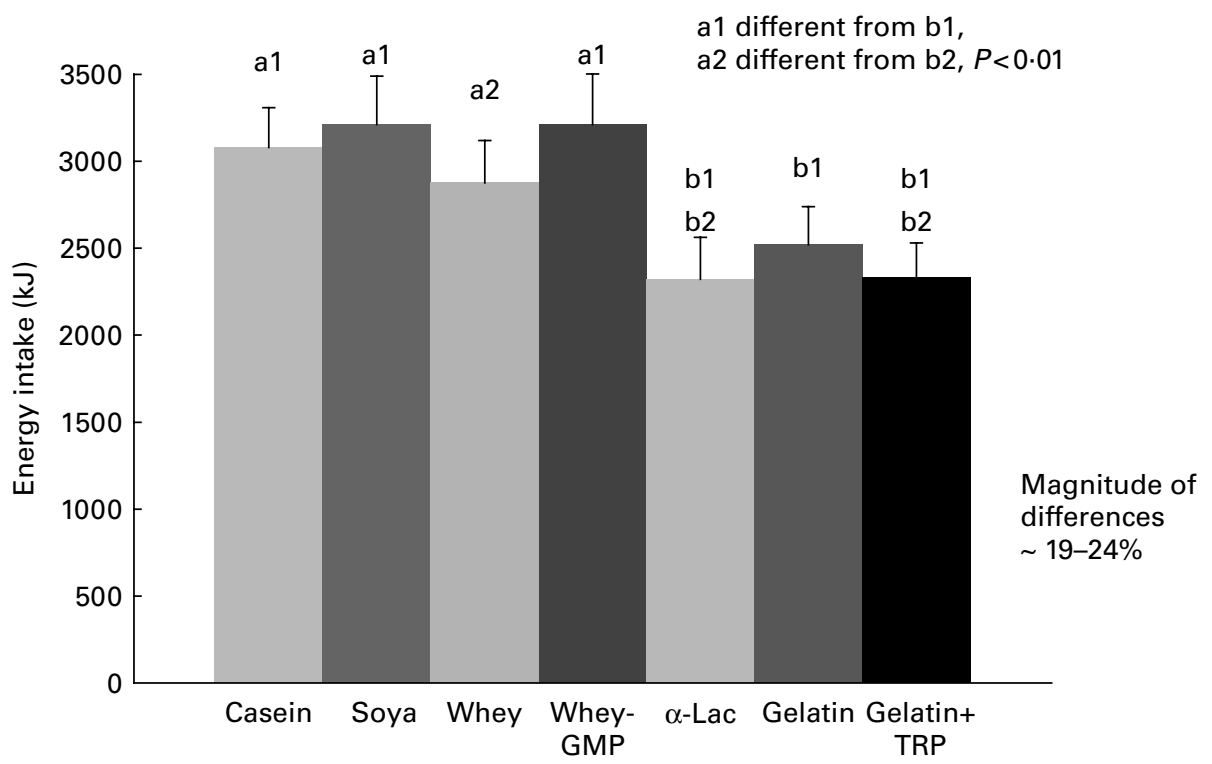

Fig. 4. Energy intake three hours after an iso-energetic, iso-volumetric semi-solid breakfast, with the same controlled appearance, taste, flavour, energy-density and viscosity, at $20 \%$ of the energy-requirement of the individual subject, and with a single protein dosage of $25 \%$ of energy. $\mathrm{N}=24$. Comparison between postprandial effects of 7 different proteins, namely casein, soya, whey, whey-GMP, alpha-lactalbumin, gelatin, gelatin plus tryptophan. After Veldhorst et al., 2009 ${ }^{(39)}$.

a sensing mechanism stresses the physiological importance of maintaining an adequate rate of protein synthesis. When ingested in surplus of the needs for postprandial protein synthesis, amino acids can readily be used as a substrate for oxidation. In elderly women, increasing the amount of dietary protein from 10 to $20 \mathrm{En} \%$ resulted in a $63 \%$ to $95 \%$ increase in protein oxidation, depending on the protein source ${ }^{(45)}$. The largest increase in protein oxidation (95\%) was observed when the predominant protein source was of animal origin, whereas this increase was only $63 \%$ when soya protein was the predominant protein source in the diet ${ }^{(45)}$. Accordingly, as mentioned in the previous section, Mikkelsen et al. ${ }^{(35)}$ observed a higher diet-induced thermogenesis with pork meat than with soya protein. Differences in digestion rate of the various protein sources may contribute to differences in postprandial protein oxidation. Thus, in comparison with slowly digested protein, ingestion of rapidly digested protein results in a stronger increase in postprandial protein synthesis and amino acid oxidation ${ }^{(46,47,48)}$. The metabolic efficacy of protein oxidation largely depends on the amino acid composition of the protein, since large differences exist with respect to the efficacy by which amino acids are oxidized. This is due to the large variety of carbon chains and cofactors that result from amino acid catabolism ${ }^{(49)}$. For instance, the number of amino groups that undergo conversion to urea in the urea cycle (at a cost of 4 ATP) ranges from one for an amino acid such as proline or alanine to three for histidine ${ }^{(49,50)}$. Taking into account the stoichiometry of amino acid catabolism and urea synthesis, the calculated energy expenditure to produce ATP ranges from $153 \mathrm{~kJ} /$ ATP for cysteine to $99 \mathrm{~kJ} /$ ATP for glutamate (for glucose, this value is $91 \mathrm{~kJ} / \mathrm{ATP})^{(50)}$. Thus, even though the ATP for urea production can be derived from subsequent oxidation of the remaining carbon group itself ${ }^{(51)}$, the metabolic efficacy of amino acid oxidation is relatively low (for glucose and fatty acids, the calculated energy expenditure to produce ATP is 91 and $96 \mathrm{~kJ} / \mathrm{ATP}$, respectively). This relative metabolic inefficiency may contribute to the higher diet-induced energy expenditure of a high-protein meal, which, in turn, has been shown to be related to subjective feelings of satiety.

\section{Summary and conclusion}

The solution for the co-morbidity related chronic disease, obesity implies BW loss and BW maintenance. Sustained satiety despite negative energy balance, sustained basal energy expenditure despite BW loss, a sparing of FFM (being the main determinant of basal energy expenditure) are conditional for BW management. Dietary protein acts on the metabolic targets involved in satiety, energy expenditure, and the sparing of FFM. The required daily intake needs to be $0.8-1.2 \mathrm{~g} / \mathrm{kg} \mathrm{BW}$, implying sustaining the original absolute protein intake and only carbohydrate and fat restriction during an energy restricted diet. The intake of $1.2 \mathrm{~g} / \mathrm{kg} \mathrm{BW}$ is beneficial to body composition and improves blood pressure. A too low absolute protein content of the diet contributes to the risk of BW regain. Including specific proteins, such as gelatin or alpha-lactalbumin, because of their high satiating capacities, does not improve the effect described.

The success of the so-called 'low carb' diet that is usually high in protein can be attributed to the relatively high-protein content per se, which underscores the even greater success, and not to the relatively lower carbohydrate content. Lowered carbohydrate intake per se has no effect on decrease in BW and $\mathrm{BF} \%$ during energy restriction, while daily elevated absolute protein intake of $1.1 \mathrm{vs} .0 \cdot 7 \mathrm{~g} / \mathrm{kg}$ BW promotes BW loss while reducing $\mathrm{BF} \%$.

Metabolic syndrome parameters restore, mainly due to BW loss. With the indicated dosage, no kidney problems have been shown in healthy individuals. Mechanisms behind 
sustained energy expenditure despite negative energy balance are the protein-related high diet-induced thermogenesis of 20-30\%, due to protein turn-over, urea production, and gluconeogenesis. Complete dietary proteins achieve a more positive protein balance than incomplete dietary proteins; with the latter more gluconeogenesis occurs. Mechanisms behind sustained satiety despite negative energy balance are elevated, (especially ketogenic), plasma amino acid concentrations, diet-induced thermogenesis, protein-type dependent hunger suppression, and in the case of a 'low carb'-protein diet, ketogenesis.

Evidence for the role of anorexic and orexigenic hormones is still scarce.

In conclusion, dietary protein plays an important role in health, since it contributes to the treatment of the chronic disease of obesity and the metabolic syndrome, by acting on the relevant metabolic targets of satiety and energy expenditure in negative energy balance, thereby preventing a weight cycling effect.

\section{Acknowledgements}

M. S. Westerterp-Plantenga wrote the main part of the manuscript. The manuscript was edited completely by S. G. Lemmens; K. R. Westerterp wrote the parts on energy expenditure and energy turn-over. The authors state that there are no conflicts of interest. Preparing the manuscript was performed without a specific grant from any funding agency in the public, commercial or not-for-profit sectors.

\section{References}

1. Pi-Sunyer FX (1993) Medical hazards of obesity. Ann Intern Med 119, 655-660.

2. Seidell JC (1995) Obesity in Europe. Obes Res 3, 89-93S.

3. Westerterp-Plantenga MS, Natalie Luscombe-Marsh N, Lejeune MPGM, et al. (2006) Dietary protein, metabolism, and body-weight regulation: dose-response effects. Int J Obes Relat Metab Disord 30, S16-S23.

4. Westerterp-Plantenga MS, Nieuwenhuizen A, Tome D, et al. (2009) Dietary protein, weight loss, and weight maintenance. Annu Rev Nutr 29, 21-41.

5. Weigle DS, Breen PA, Matthys CC, et al. (2005) A highprotein diet induces sustained reductions in appetite, ad libitum caloric intake, and body weight despite compensatory changes in diurnal plasma leptin and ghrelin concentrations. Am J Clin Nutr 82, 41-48.

6. Stock MJ (1999) Gluttony and thermogenesis revisited. Int J Obes Relat Metab Disord 23, 1105-1117.

7. Skov AR, Toubro S, Ronn B, et al. (1999) Randomized trial on protein vs carbohydrate in ad libitum fat reduced diet for the treatment of obesity. Int J Obes Relat Metab Disord 23, 528-536.

8. Westerterp-Plantenga MS, Lejeune MP, Nijs I, et al. (2004) High protein intake sustains weight maintenance after body weight loss in humans. Int J Obes Relat Metab Disord 28, 57-64.

9. Halton TL \& Hu FB (2005) The effects of high protein diets on thermogenesis, satiety and weight loss: a critical review. J Am Coll Nutr 23, 373-385.
10. Lejeune MP, Kovacs EM \& Westerterp-Plantenga MS (2005) Additional protein intake limits weight regain after weight loss in humans. Br J Nutr 93, 281-289.

11. Noakes M, Keogh JB, Foster PR, et al. (2005) Effect of an energy-restricted, high-protein, low-fat diet relative to a conventional high-carbohydrate, low-fat diet on weight loss, body composition, nutritional status, and markers of cardiovascular health in obese women. Am J Clin Nutr 81, 1298-1306.

12. Krieger JW, Sitren HS, Daniels MJ, et al. (2006) Effects of variation in protein and carbohydrate intake on body mass and composition during energy restriction: a meta-regression analysis. Am J Clin Nutr 83, 260-274.

13. Sacks FM, Bray GA, Carey VJ, et al. (2009) Comparison of weight-loss diets with different compositions of fat, protein, and carbohydrates. $N$ Engl J Med 360, 859-873.

14. Larsen TM, Dalskov SM, van Baak M, et al. (2010) Diet, Obesity, and Genes (Diogenes) Project. Diets with high or low protein content and glycemic index for weight-loss maintenance. $N$ Engl J Med 363, 2102-2113.

15. Deibert P, Konig D, Schmidt-Trucksaess A, et al. (2004) Weight loss without losing muscle mass in pre-obese and obese subjects induced by a high-soy-protein diet. Int J Obes Relat Metab Disord 28, 1349-1352.

16. Farnsworth E, Luscombe ND, Noakes M, et al. (2003) Effect of a high-protein, energy-restricted diet on body composition, glycemic control, and lipid concentrations in overweight and obese hyperinsulinemic men and women. Am J Clin Nutr 78, 31-39.

17. Layman DK, Boileau RA, Erickson DJ, et al. (2003) A reduced ratio of dietary carbohydrate to protein improves body composition and blood lipid profiles during weight loss in adult women. J Nutr 133, 411-417.

18. Luscombe ND, Clifton PM, Noakes M, et al. (2002) Effects of Energy-Restricted Diets Containing Increased Protein on Weight Loss, Resting Energy Expenditure, and the Thermic Effect of Feeding in Type 2 Diabetes. Diabetes Care 25 , 652-657.

19. Luscombe ND, Clifton PM, Noakes M, et al. (2003) Effect of a high-protein, energy-restricted diet on weight loss and energy expenditure after weight stabilization in hyperinsulinemic subjects. Int J Obes Relat Metab Disord 27, 582-590.

20. Brinkworth GD, Noakes M, Keogh JB, et al. (2004) Longterm effects of a high-protein, low-carbohydrate diet on weight control and cardiovascular risk markers in obese hyperinsulinemic subjects. Int J Obes Relat Metab Disord 28, 661-670.

21. Soenen S \& Westerterp-Plantenga MS (2010) Changes in body fat percentage during body weight stable conditions of increased daily protein intake vs. control. Physiol Behav 101, 635-638.

22. Soenen S, Plasqui G, Smeets AJ, et al. (2010) Protein intake induced an increase in exercise stimulated fat oxidation during stable body weight. Physiol Behav 101, 770-774.

23. Hochstenbach-Waelen A, Soenen S, Westerterp KR, et al. (2011) Effects of a supra-sustained gelatin-milk protein diet compared with (supra-)sustained milk protein diets on body-weight loss. Br J Nutr 105, 1388-1398.

24. Hochstenbach-Waelen A, Westerterp KR, Soenen S, et al. (2010) No long-term weight maintenance effects of gelatin in a supra-sustained protein diet. Physiol Behav 101, $237-244$.

25. Soenen S, Hochstenbach-Waelen A \& Westerterp-Plantenga MS (2011) Efficacy of $\alpha$-lactalbumin and milk protein on weight loss and body composition during energy restriction. Obesity 19, 370-379. 
26. Johnstone AM, Horgan GW, Murison SD, et al. (2008) Effects of a high-protein ketogenic diet on hunger, appetite, and weight loss in obese men feeding ad libitum. Am J Clin Nutr 87, 44-55.

27. Robinson AM \& Williamson DH (1980) Physiological roles of ketone bodies as substrates and signals in mammalian tissues. Physiol rev 60, 143-187.

28. Scharrer E (1999) Control of food intake by fatty acid oxidation and ketogenesis. Nutrition 15, 704-714.

29. Veldhorst MA, Westerterp-Plantenga MS \& Westerterp KR (2009) Gluconeogenesis and energy expenditure after a high-protein, carbohydrate-free diet. Am J Clin Nutr 90, 519-526.

30. Veldhorst MA, Westerterp KR, van Vught AJ, et al. (2010) Presence or absence of carbohydrates and the proportion of fat in a high-protein diet affect appetite suppression but not energy expenditure in normal-weight human subjects fed in energy balance. BrJ Nutr 104, 1395-1405.

31. Westerterp KR, Wilson SAJ \& Rolland A (1999) Diet-induced thermogenesis measured over $24 \mathrm{~h}$ in a respiration chamber: effect of diet composition. Int J Obes Relat Metab Disord 23, 287-292

32. Westerterp-Plantenga MS, Rolland V, Wilson SA, et al. (1999) Satiety related to $24 \mathrm{~h}$ diet-induced thermogenesis during high protein/carbohydrate vs high fat diets measured in a respiration chamber. Eur J Clin Nutr 53, 495-502.

33. Hochstenbach-Waelen A, Veldhorst MA, Nieuwenhuizen AG, et al. (2009) Comparison of 2 diets with either $25 \%$ or $10 \%$ of energy as casein on energy expenditure, substrate balance, and appetite profile. Am J Clin Nutr 89, 831-838.

34. Hochstenbach-Waelen A, Westerterp-Plantenga MS, Veldhorst MA, et al. (2009) Single-protein casein and gelatin diets affect energy expenditure similarly but substrate balance and appetite differently in adults. J Nutr $\mathbf{1 3 9}$, 2285-2292.

35. Mikkelsen PB, Toubro S \& Astrup A (2000) Effect of fatreduced diets on 24-h energy expenditure: comparisons between animal protein, vegetable protein and carbohydrate. Am J Clin Nutr 72, 1135-1141.

36. Lejeune MPGM, Westerterp KR, Adam TC, et al. (2006) Ghrelin and glucagon-like peptide 1 concentrations, 24-h satiety, and energy and substrate metabolism during a high-protein diet and measured in a respiration chamber. Am J Clin Nutr 83, 89-94.

37. Westerterp-Plantenga MS, Lejeune MPGM, Smeets AJPG, et al. (2009) Sex differences in energy homeostasis following a diet relatively high in protein exchanged with carbohydrate, assessed in a respiration chamber in humans. Physiol Behav 22, 414-419.

38. Mellinkoff SM, Frankland M, Boyle D, et al. (1956) Relationship between serum amino acid concentration and fluctuations in appetite. J Appl Physiol 8, 535-538.

39. Veldhorst MA, Nieuwenhuizen AG, Hochstenbach-Waelen A, et al. (2009) A breakfast with alpha-lactalbumin, gelatin, or gelatin + TRP lowers energy intake at lunch compared with a breakfast with casein, soy, whey, or whey-GMP. Clin Nutr 28, 147-155.

40. Veldhorst MA, Nieuwenhuizen AG, Hochstenbach-Waelen A, et al. (2009) Dose-dependent satiating effect of whey relative to casein or soy. Physiol Behav 96, 675-682.

41. Veldhorst MA, Nieuwenhuizen AG, Hochstenbach-Waelen A, et al. (2009) Effects of complete whey-protein breakfasts versus whey without GMP-breakfasts on energy intake and satiety. Appetite 52, 388-395.

42. Nieuwenhuizen AG, Hochstenbach-Waelen A, Veldhorst MA, et al. (2009) Acute effects of breakfasts containing alphalactalbumin, or gelatin with or without added tryptophan, on hunger, 'satiety' hormones and amino acid profiles. $\mathrm{Br}$ J Nutr 101, 1859-1866.

43. Gietzen DW, Hao S \& Anthony TG (2007) Mechanisms of food intake repression in indispensable amino acid deficiency. Annu Rev Nutr 27, 63-78.

44. Tome D (2004) Protein, amino acids and the control of food intake. Br J Nutr 92, S27-S30.

45. Pannemans DL, Wagenmakers $\mathrm{AJ}$, Westerterp $\mathrm{KR}$, et al. (1998) Effect of protein source and quantity on protein metabolism in elderly women. Am $J$ Clin Nutr 68 , $1228-1235$

46. Boirie Y, Dangin M, Gachon P, et al. (1997) Slow and fast dietary proteins differently modulate postprandial protein accretion. Proc Natl Acad Sci USA 94, 14930-14935.

47. Dangin M, Boirie Y, Garcia-Rodenas C, et al. (2001) The digestion rate of protein is an independent regulating factor of postprandial protein retention. Am J Physiol Endocrinol Metab 280, E340-E348.

48. Dangin M, Boirie Y, Guillet C, et al. (2002) Influence of the protein digestion rate on protein turnover in young and elderly subjects. J Nutr 132, 3228S-3233S

49. Stryer L (1988) Biochemistry. New York: Freeman.

50. van Milgen J (2002) Modeling biochemical aspects of energy metabolism in mammals. J Nutr 132, 3195-3202.

51. Jungas RL, Halperin ML \& Brosnan JT (1992) Quantitative analysis of amino acid oxidation and related gluconeogenesis in humans. Physiol Rev 72, 419-448. 